\title{
Norwogonin attenuates hypoxia-induced oxidative stress and apoptosis in PC12 cells
}

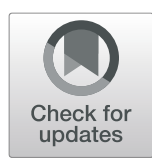

\author{
Linlin Jing ${ }^{\dagger}$, Rongmin $\mathrm{Gao}^{\dagger}$, Jie Zhang, Dongmei Zhang, Jin Shao, Zhengping Jia and Huiping Ma* (D)
}

\begin{abstract}
Background: Norwogonin is a natural flavone with three phenolic hydroxyl groups in skeletal structure and has excellent antioxidant activity. However, the neuroprotective effect of norwogonin remains unclear. Here, we investigated the protective capacity of norwogonin against oxidative damage elicited by hypoxia in PC12 cells.

Methods: The cell viability and apoptosis were examined by MTT assay and Annexin V-FITC/PI staining, respectively. Reactive oxygen species (ROS) content was measured using DCFH-DA assay. Lactate dehydrogenase (LDH), malondialdehyde (MDA) and antioxidant enzyme levels were determined using commercial kits. The expression of related genes and proteins was measured by real-time quantitative PCR and Western blotting, respectively.

Results: We found that norwogonin alleviated hypoxia-induced injury in PC12 cells by increasing the cell viability, reducing LDH release, and ameliorating the changes of cell morphology. Norwogonin also acted as an antioxidant by scavenging ROS, reducing MDA production, maintaining the activities of superoxide dismutase (SOD), catalase (CAT) and glutathione peroxidase (GPX), and decreasing the expression levels of HIF-1a and VEGF. In addition, norwogonin prevented cell apoptosis via inhibiting the expression levels of caspase-3, cytochrome $\mathrm{c}$ and Bax, while increasing the expression levels of $\mathrm{BCl}-2$ and the ratio of $\mathrm{BCl}-2 / \mathrm{Bax}$.
\end{abstract}

Conclusions: Norwogonin attenuates hypoxia-induced injury in PC12 cells by quenching ROS, maintaining the activities of antioxidant enzymes, and inhibiting mitochondrial apoptosis pathway.

Keywords: Norwogonin, Antioxidant activity, Hypoxia, Oxidative stress, Apoptosis

\section{Background}

Aerobic organisms need oxygen $\left(\mathrm{O}_{2}\right)$ for producing energy. Hypoxia is defined as insufficient $\mathrm{O}_{2}$ supply to maintain cellular function in tissue and often occurs in some physiological situations such as high altitude [1], and in many pathological situations such as stroke [2]. The brain is particularly sensitive to hypoxia-induced injury due to its high oxygen consumption, rich in unsaturated fatty acids and low antioxidant capacity [3]. Increasing evidences have indicated that hypoxia can induce adverse effects on brain [4-6].

\footnotetext{
* Correspondence: huipingmacyk@163.com

${ }^{\dagger}$ Linlin Jing and Rongmin Gao contributed equally to this work as co-first authors

Department of Pharmacy, the 940th Hospital of Joint Logistics Support force of PLA, Lanzhou 730050, Gansu, China
}

Oxidative stress and apoptosis are considered as two contributing factors in hypoxia-induced injury [7, 8]. Hypoxia exposure has been reported to increase the production of intracellular reactive oxygen species (ROS), which facilitates oxidative stress. Excessive ROS, such as superoxide anion $\left(\mathrm{O}_{2}{ }^{-}\right)$, hydrogen peroxide $\left(\mathrm{H}_{2} \mathrm{O}_{2}\right)$ and hydroxyl radical $(\mathrm{HO} \bullet)$, leads to structural and functional cellular changes by attacking lipids, membranes, proteins and DNA, and subsequently causes cell damage [9]. Simultaneously, overproduced ROS also facilitates opening of mitochondrial permeability transition pore (mPTP) [10] and transferring pro-apoptosis proteins to the outer mitochondrial membrane, which induces depolarization of mitochondrial membranes and releases of cytochrome $\mathrm{c}$ [11]. These changes ultimately cause mitochondrialdependent apoptosis [12]. So, it is believed that

(c) The Author(s). 2021 Open Access This article is licensed under a Creative Commons Attribution 4.0 International License, which permits use, sharing, adaptation, distribution and reproduction in any medium or format, as long as you give appropriate credit to the original author(s) and the source, provide a link to the Creative Commons licence, and indicate if changes were made. The images or other third party material in this article are included in the article's Creative Commons licence, unless indicated otherwise in a credit line to the material. If material is not included in the article's Creative Commons licence and your intended use is not permitted by statutory regulation or exceeds the permitted use, you will need to obtain permission directly from the copyright holder. To view a copy of this licence, visit http://creativecommons.org/licenses/by/4.0/ The Creative Commons Public Domain Dedication waiver (http://creativecommons.org/publicdomain/zero/1.0/) applies to the data made available in this article, unless otherwise stated in a credit line to the data. 
antioxidant with the ability of inhibiting or eliminating excessive ROS may exert its protective effect via attenuating oxidative stress and apoptosis induced by hypoxia. Lots of studies have proved that antioxidant supplement like vitamin C [13], isoflavone [8] and nitroxide radicals [14], can limit hypoxia-induced injury in vitro and in vivo.

Flavonoids are large and diverse class of ubiquitous plant secondary metabolites. They are always considered as excellent natural antioxidant with the ability of scavenging free radical and inhibiting lipid peroxidation. Currently, more and more attentions have been paid on this class of compounds due to their benefit effects on human health. Flavonoids have been shown to own a wide range of pharmacological actions, such as antiinflammatory, antinociceptive and neuroprotective activity, etc., all which may be attribute to their antioxidant activities [15]. Many studies have indicated that flavonoids exhibit excellent protective effects on hypoxia-induced failure. For example, rutin has a strong neuroprotective effect against retinal ganglion cell death induced by hypoxia [16]. A recent study also demonstrates that rutin can alleviate cobalt chloride-induced hypoxia damage by inhibiting oxidative stress and apoptosis in H9c2 cell [17]. Moreover, Liu et al suggest that nobiletin $\left(3^{\prime}, 4^{\prime}, 5,6\right.$, 7,8-hexamethoxyflavone) attenuates myocardial $I / R$ injury via activating of Akt/GSK-3 $\beta$ pathway in $\mathrm{H} 9 \mathrm{c} 2$ cell [18]. In addition, acacetin can protect rat cardiomyocytes and $\mathrm{H} 9 \mathrm{C} 2$ cardiomyoblasts against hypoxia/reoxygenation induced injury via AMPK-mediated activation of Nrf2 signaling pathway [19].

Norwogonin (5,7,8-trihydroxyflavone, Fig. 1) is a pharmacologically active flavone separated from the root of Scutellaria baicalensis Georgi ("Huang Qin" in Chinese), a traditional Chinese herb used to treat fluenza and cancer [20, 21]. However, limited studies have been reported on the biological activities of norwogonin due to its low levels in natural plants. In order to address this problem, several synthesis methods of norwogonin are reported [22, 23]. Our previous study also established a simple method for obtaining norwogonin from chrysin in four steps [24]. These researches have positively influenced the further evaluation of norwogonin's biological activities.

Studies have revealed that norwogonin owns antioxidant [25], anticancer [26, 27], antiviral [28] and antimicrobial activities [29] as well as inhibits the cyanidestimulated production of ROS [30]. However, whether norwogonin has protective capacities against hypoxiainduced injury remains unknown. The aim of present study was to investigate the protective effects of norwogonin against hypoxia-induced oxidative stress and apoptosis in PC12 cells.

\section{Methods}

\section{Materials and reagents}

Norwogonin (purity $\geq 98 \%$ ) was synthesized according to our previous reported method [24]. Rutin (purity $\geq 96 \%$ ) was purchased from Ci Yuan Biotechology Co., Ltd. (Xian, Shannxi, China). Norwogonin and rutin was dissolved in sterile dimethyl sulfoxide (DMSO), stored at $20^{\circ} \mathrm{C}$, and diluted in the cell culture medium immediately before using.

Dulbecco's modified Eagle's medium (DMEM), fetal bovine serum (FBS), streptomycin and penicillin were purchased from Solarbio co., Ltd. (Beijing, China).

The kits of malondialdehyde (MDA), lactate dehydrogenase (LDH), superoxide dismutase (SOD), catalase (CAT) and glutathione peroxidase (GPx) were obtained from Nanjing Jiancheng Bioengineering Institute (Jiangsu, China). 2',7'-dichlorodi-hydrofluorescein diacetate (DCFH-DA) and (3-(4,5-dimethylthiazol-2-yl)-2,5diphenyltetrazolium bromide) tetrazolium (MTT) was obtained from Sigma-Aldrich Co (St. Louis, MO, USA). Primary antibodies for hypoxia inducible factor- $1 \alpha$ (HIF-

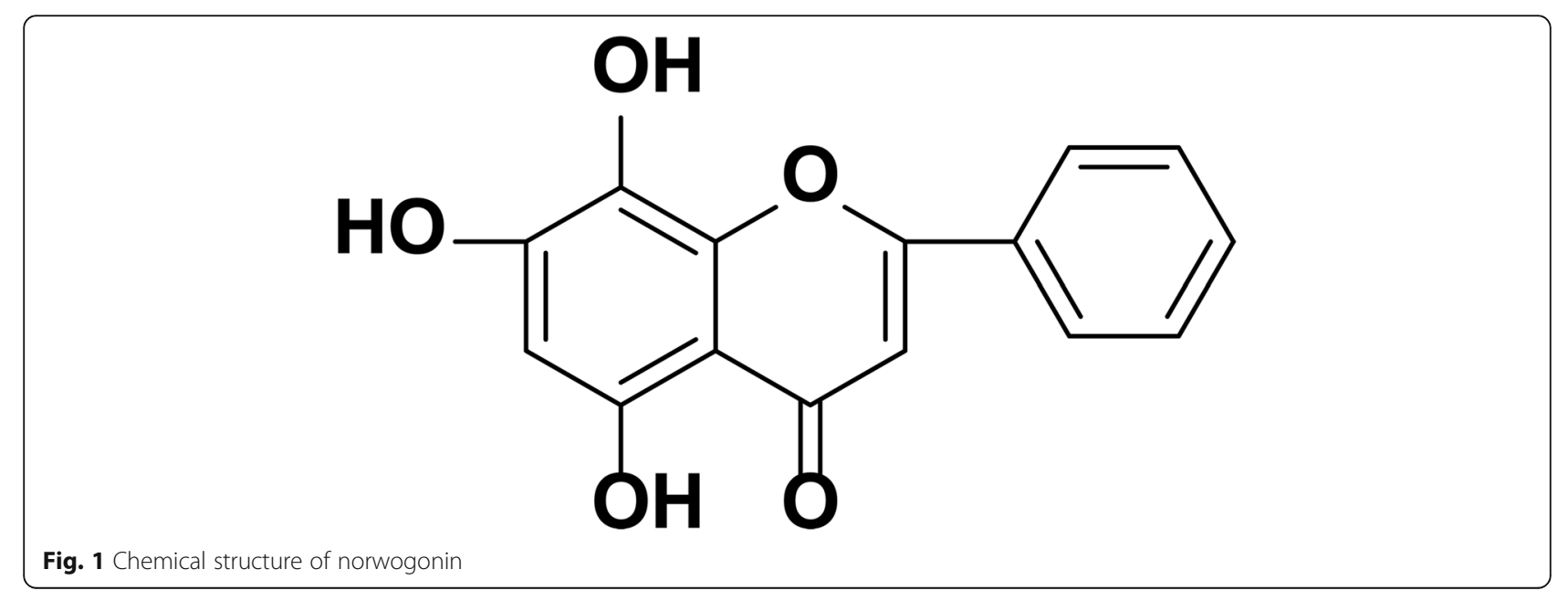


$1 \alpha)$, vascular endothelial growth factor (VEGF), B cell lymphoma-2 (Bcl-2), Bcl-2 associated $\mathrm{X}$ protein (Bax), Caspase-3, Cytochrome $\mathrm{C}$ and $\beta$-actin were all purchased from Abcam (Cambridge, UK). Secondary antibodies were obtained from ZsBio Company (Beijing, China). Apoptosis analysis kit was obtained from Beyotime Institute of Biotechnology (Jiangsu, China). All chemicals and solvents were of analytical grade and were obtained from commercial supplier in China.

\section{Cell culture}

The PC12 cells were purchased from Cell Bank of the Chinese Academy of Sciences (TCR 9, Shanghai, China) and maintained in DMEM with $10 \%(\mathrm{v} / \mathrm{v})$ FBS, $100 \mathrm{U} /$ $\mathrm{mL}$ penicillin, and $100 \mathrm{U} / \mathrm{mL}$ streptomycin at $37^{\circ} \mathrm{C}$ in a humidified incubator containing $5 \% \mathrm{CO}_{2}$.

To evaluate the cytotoxicity of norwogonin, PC12 cells (passage $4 \sim 6$ ) were pre-incubated with different concentrations $\left(10^{-8}, 10^{-7}, 10^{-6}, 10^{-5}, 10^{-4} \mathrm{~mol} / \mathrm{L}\right)$ of norwogonin for $1 \mathrm{~h}$ and then cultured for $24 \mathrm{~h}$.

\section{Hypoxia exposure}

To induce cell hypoxia injury model, PC12 cells were subjected to hypoxia environment $\left(1 \% \mathrm{O}_{2}, 5 \% \mathrm{CO}_{2}\right.$, and $94 \% \mathrm{~N}_{2}$ ) at $37^{\circ} \mathrm{C}$ for $24 \mathrm{~h}$ in a humidified chamber. Normoxic control cells were cultured at $37^{\circ} \mathrm{C}$ in a $5 \% \mathrm{CO}_{2}$ incubator for $24 \mathrm{~h}$.

To evaluate the protective effect of norwogonin against hypoxia-induced injury, $\mathrm{PC} 12$ cells were preincubated with different concentrations $\left(10^{-8}, 10^{-7}\right.$, $10^{-6}, 10^{-5} \mathrm{~mol} / \mathrm{L}$ ) of norwogonin for $1 \mathrm{~h}$ before hypoxia treatment.

\section{Cell viability}

The cells viability was measured by MTT assay as previously described [31]. In brief, PC12 cells $\left(1 \times 10^{5}\right.$ cells/ $\mathrm{mL}$ ) were seeded in 96 well culture plates. Then different concentrations of norwogonin were added to the wells. Equal volume of DMSO was added to control wells. The final concentration of DMSO in the cell culture medium is $0.1 \%$. After incubation at normoxic or hypoxia condition, $10 \mu \mathrm{L}$ of MTT $(5.0 \mathrm{mg} / \mathrm{mL})$ was added to each well, followed by incubation at $37^{\circ} \mathrm{C}$ for $4 \mathrm{~h}$. Then, the supernatant with MTT was removed and the formazan product was dissolved in $100 \mu \mathrm{L}$ DMSO. The absorbance was measured on a SpectraMax i3 microplate reader (Molecular Devices, Sunnyvale, CA, USA) at $570 \mathrm{~nm}$. The results were expressed as the relative percentage of control group.

\section{Hematoxylin and eosin (HE) staining}

PC12 cells seeded on glass coverslips were incubated for $24 \mathrm{~h}$ before they were treated with norwogonin in the same way as described above. The medium was removed and the glass coverslips were washed with cold PBS, followed by fixation with methanol for $10 \mathrm{~min}$ at room temperature and then washed with cold PBS three times for $5 \mathrm{~min}$. Finally the cells were stained according to the HE staining protocol [32]. The analyses of the cell were performed using an OLYMPUS IX73 microscope (100x) in order to verify cell morphological changes. Digital images were obtained using the DXM $1200 \mathrm{C}$ digital camera (Nikon) associated to the microscope.

\section{ROS content}

Intracellular ROS level in PC12 cells was determined using DCFH-DA assay [33]. Briefly, PC12 cells $\left(1 \times 10^{5}\right.$ cells $/ \mathrm{mL}$ ) were seeded in 6-well plates. After hypoxia treatment, PC12 cells were washed with PBS, and then were incubated in the culture medium containing $10 \mu \mathrm{M}$ DCFH-DA for $30 \mathrm{~min}$ in the dark at $37^{\circ} \mathrm{C}$. The cells were observed with Olympus inverted fluorescence microscope (Tokyo, Japan) and were analyzed by a Becton Dickinson FACScan flow cytometer (BD Biosciences, CA, USA) with excitation wavelength of $488 \mathrm{~nm}$ and emission wavelength of $525 \mathrm{~nm}$. The ROS level was expressed as relative percentage of control.

\section{LDH leakage, MDA content and antioxidant enzyme activity}

PC12 cells $\left(1 \times 10^{5}\right.$ cells $\left./ \mathrm{mL}\right)$ were seeded in $90 \mathrm{~mm}$ dish. After hypoxia treatment as described above, $50 \mu \mathrm{L}$ culture supernatant from each dish were collected, and LDH activity in medium was detected using commercial assay kits (Jiancheng Institute of Biotechnology, Nanjing, China) and was expressed as $\mathrm{U} / \mathrm{mL}$. The PC12 cells were harvested and homogenized after washing two times with cold PBS. The concentration of total protein was measured by BCA protein assay kit. The MDA content and antioxidant enzyme activity were determined using commercial assay kits (Jiancheng Institute of Biotechnology, Nanjing, China). The content of MDA was presented as nmol/mg protein. The activities of SOD, CAT and GPx were presented as $\mathrm{U} / \mathrm{mg}$ protein.

\section{Cell apoptosis(Annexin-V/PI staining)}

After hypoxia treatment, PC12 cells were harvested, washed two times with cold PBS, and then suspended with binding buffer. The cells were treated with the Annexin V-FITC and PI solution following the protocol of the manufacturer (Beyotime, Shanghai, China). Data collections were performed using Becton Dickinson FACScan flow cytometer (BD Biosciences, CA, USA).

\section{Quantitative real-time PCR analysis}

The total RNA of PC12 cells was extracted using Trizol reagent (Takara, Dalian, China) and converted to cDNA using the PrimeScript TM RT reagent Kit (AK4301, 
Takara, Dalian, China). The cDNA encoding HIF- $1 \alpha$, VEGF, Bcl-2, Bax, caspase-3, cytochrome $\mathrm{C}$ and glyceraldehyde-3-phosphate dehydrogenase (GAPDH) gene was amplified by Quantitative real-time PCR using a 7300 real-time detection System (Applied Biosystems, CA, USA). The primers used were shown in Table 1. The PCR cycling conditions were $95^{\circ} \mathrm{C}$ for $30 \mathrm{~s}$, follow by 40 cycles of $95^{\circ} \mathrm{C}$ for $5 \mathrm{~s}$ and $60^{\circ} \mathrm{C}$ for $31 \mathrm{~s}$. The mRNA levels were calculated using the $2^{-\Delta \Delta \mathrm{Ct}}$ method and normalized to GAPDH, which as the reference gene.

\section{Western blot}

PC12 cells were harvested and homogenized in RIPA agents. The concentration of total proteins was quantified using BCA protein assay kit. $30 \mu \mathrm{g}$ of samples were resolved on 12\% SDS-PAGE electrophoresis and then transferred to polyvinylidene fluoride (PVDF) membranes (Millipore, Billerica, MA, USA). The membranes were blocked with $5 \%$ non-fat dry milk in TBST buffer for $1 \mathrm{~h}$ at room temperature and incubated with primary antibodies: anti-HIF- $1 \alpha$ (1:300, ab179483, Abcam, UK), anti-VEGF (1:1000, ab46154, Abcam, UK), anti-Bcl-2 (1:1000, ab59348, Abcam, UK), anti-Bax (1:500, ab32503, Abcam, UK), anticaspase-3 (1:300, ab44976, Abcam, UK), anticytochrome C (1:1000, ab13575, Abcam, UK) and anti- $\beta$-actin (1:2000, ab8227, Abcam, UK) at $4{ }^{\circ} \mathrm{C}$ overnight. Then, the membranes were washed and incubated with secondary antibodies (1:2000, ZsBio, Beijing, China;) for $1 \mathrm{~h}$ at room temperature. The immunoreactive bands were visualized using enhanced chemiluminescence (ECL) reagents. The relative intensities of bands were normalized to the $\beta$-actin internal control and analyzed using Image-Pro Plus 6.0 (Media Cybernetics, Inc., Bethesda, MD, USA).

\section{Statistical analysis}

The results were expressed as mean \pm SD derived from at least three independent experiments. Difference between groups were analyzed using one-way analysis of variance (ANOVA) following by Student-NewmanKeuls post hoc test. A $P$-value of $<0.05$ was regarded as statistically significant.

\section{Results}

Norwogonin protective PC12 cells against hypoxiainduced injury

First, to preclude the proliferative activity of norwogonin, its cytotoxicity on normal PC12 cells was determined using MTT assay. As seen in Fig. 2a, cellular proliferation was not significantly changed following treatment with norwogonin at concentrations of $1 \times$ $10^{-8}-1 \times 10^{-5} \mathrm{~mol} / \mathrm{L}(P>0.05)$. However, cell viability significantly decreased when the concentration of norwogonin was increased to $1 \times 10^{-4} \mathrm{~mol} / \mathrm{L}(P<0.05)$. The results indicated that norwogonin did not exhibit toxicity or proliferative activity on PC12 cells at the concentrations of $1 \times 10^{-8}-1 \times 10^{-5} \mathrm{~mol} / \mathrm{L}$.

Then we examined the protective effect of norwogonin against hypoxia-induced PC12 cells injury. As shown in Fig. 2b, compared with the control group, the cell viability in hypoxia group was decreased to $58.71 \%(P<0.01)$. Compared with the hypoxia treatment, pretreated with $1 \times 10^{-8}, 1 \times 10^{-7}$, and $1 \times 10^{-6} \mathrm{~mol} / \mathrm{L}$ norwogonin dosedependently protected $\mathrm{PC} 12$ cells against hypoxiainduced injury, recovering the cell viability from 58.71 to 62.79\% $(P<0.05), 66.68 \%(P<0.01)$ and $69.88 \%(P<$ $0.01)$, respectively. Pretreatment with $1 \times 10^{-6} \mathrm{~mol} / \mathrm{L}$ rutin also exhibited protective effect, significantly increasing the cell viability to $63.78 \%$ compared to hypoxia treatment. The viability pretreated with $1 \times 10^{-5} \mathrm{~mol} / \mathrm{L}$ norwogonin was decreased to $63.43 \%$, which still

Table 1 Primers used in real-time qPCR

\begin{tabular}{|c|c|c|}
\hline Gene & Primer sequences & Product (bp) \\
\hline HIF-1a & $\begin{array}{l}\text { forward: 5'-CCAGATTCAAGATCAGCCAGCA-3' } \\
\text { reverse: 5'-GCTGTCCACATCAAAGCGTATA-3' }\end{array}$ & 100 \\
\hline VEGF & $\begin{array}{l}\text { forward:5'-ACATTGGCTCACTTCCAGAAACA-3' } \\
\text { reverse:5-TGGTTGGAACCGGATCTITA-3' }\end{array}$ & 108 \\
\hline $\mathrm{BCl}-2$ & $\begin{array}{l}\text { forward:5'-GGTGGTGGAGAACTCTTCACGT-3' } \\
\text { reverse:5'-AGGATTGTGGCTGAACA-3' }\end{array}$ & 253 \\
\hline Bax & $\begin{array}{l}\text { forward: 5'-TGGCGATGAACTGGACAACAA-3' } \\
\text { reverse: 5'-GGGAGTCTGTATCCACATCAGCA-3' }\end{array}$ & 65 \\
\hline Caspase-3 & $\begin{array}{l}\text { forward:5'-AGACAGACAGTGGAACTGACGATG-3' } \\
\text { reverse:5'-GGCGCAAAGTGACTGGATGA-3' }\end{array}$ & 147 \\
\hline Cytochrome C & $\begin{array}{l}\text { forward:5-GAAGAAGGGAGAAAGGGCAGA-3' } \\
\text { reverse:5'-CGGGGGCTGTCCAACAAA-3' }\end{array}$ & 302 \\
\hline GAPDH & $\begin{array}{l}\text { forward: 5'-GCCACAGTCAAGGCTGAGAATG-3' } \\
\text { reverse:5'-ATGGTGGTGAAGACGCCAGTA-3' }\end{array}$ & 143 \\
\hline
\end{tabular}




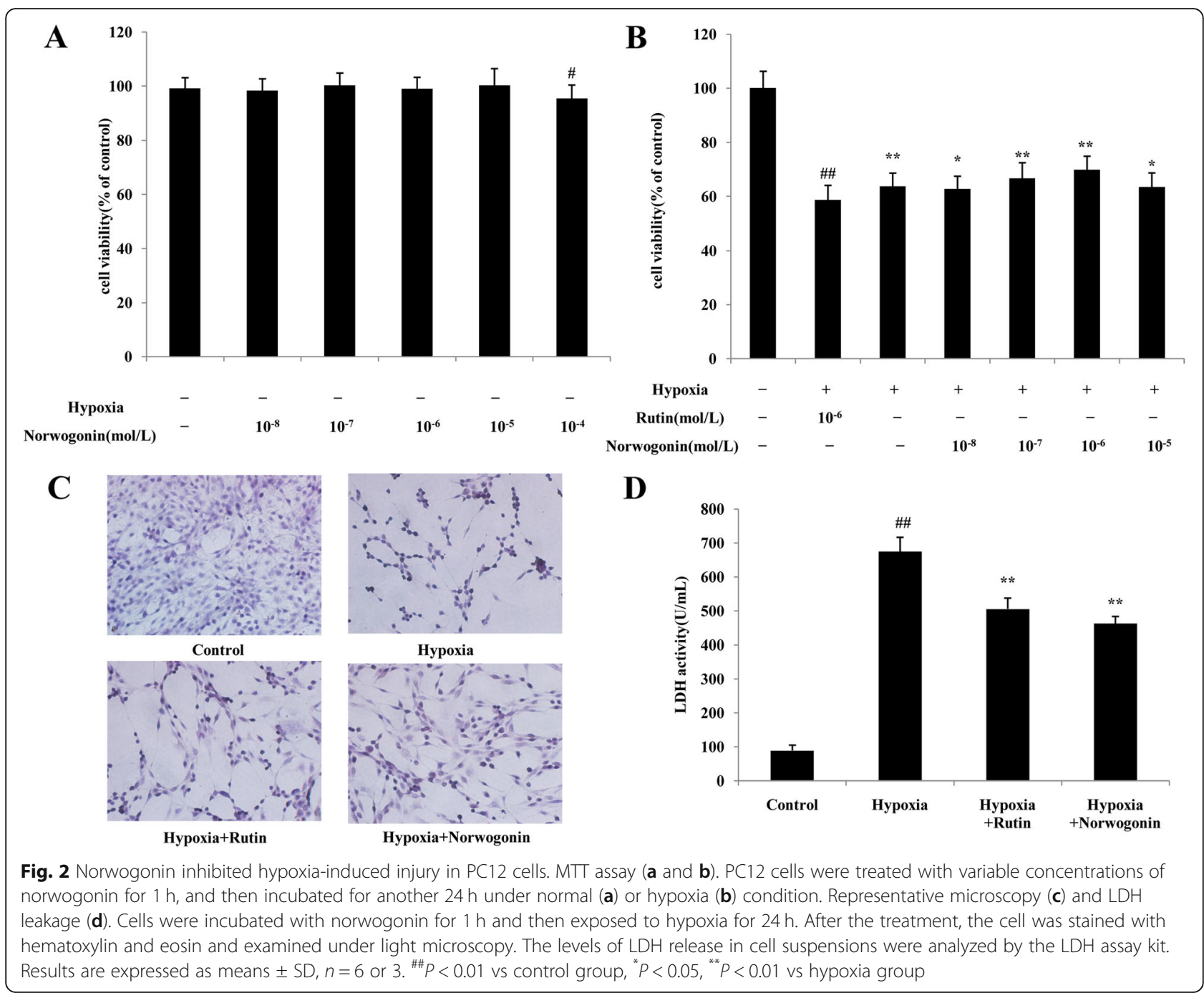

significant higher than that in hypoxia group $(P<0.05)$. These results demonstrated that norwogonin showed significant cytoprotection at the concentrations of $1 \times$ $10^{-8}-1 \times 10^{-5} \mathrm{~mol} / \mathrm{L}$ and the most effective concentration is $1 \times 10^{-6} \mathrm{~mol} / \mathrm{L}$. Then this dose was used as optimal dose in the following experiments.

The protective capacity of norwogonin was also verified by the morphological alterations. As shown in Fig. 2c, PC12 cells without hypoxia treatment grew well with regular shapes (fusiform), uniform sizes. After hypoxia exposure, PC12 cells exhibited shrinkage, rounded shape, desquamation, and reduced cell density. The cells pretreated with norwogonin or rutin before hypoxia exposure grew better, the number of desquamation cells decreased, and cell shape recovered normally.

Besides, the protective ability of norwogonin was confirmed by the LDH leakage, which is associated with the loss of cell-membrane integrity. As shown in Fig. 2d, the LDH activity in culture medium was notably increased following hypoxia exposure $(P<0.01)$. Pretreatment with norwogonin or rutin dramatically decreased the LDH leakage, suggesting norwogonin and rutin restored the cell-membrane integrity.

\section{Norwogonin inhibits hypoxia-induced oxidant stress in PC12 cells}

ROS and MDA are two important indicators of cellular oxidant stress induced by hypoxia. As shown in Fig. 3a and $\mathrm{b}$, a significant increased content of ROS and MDA was observed in PC12 cells following hypoxia exposure. Norwogonin or rutin pretreatment significantly inhibited the production of ROS and MDA. Antioxidant enzymes, such as SOD, CAT, and GPx, are regarded as the main defense system against oxidative stress in cell. As shown in Fig. 3c-e, hypoxia exposure significantly inhibited the activities of SOD, CAT, and GPx in PC12 cells. Treatment with norwogonin or rutin reversed these changes and restored the activities of antioxidant enzymes. All these results indicated that norwogonin protected the PC12 cells against oxidative stress induced by hypoxia. 


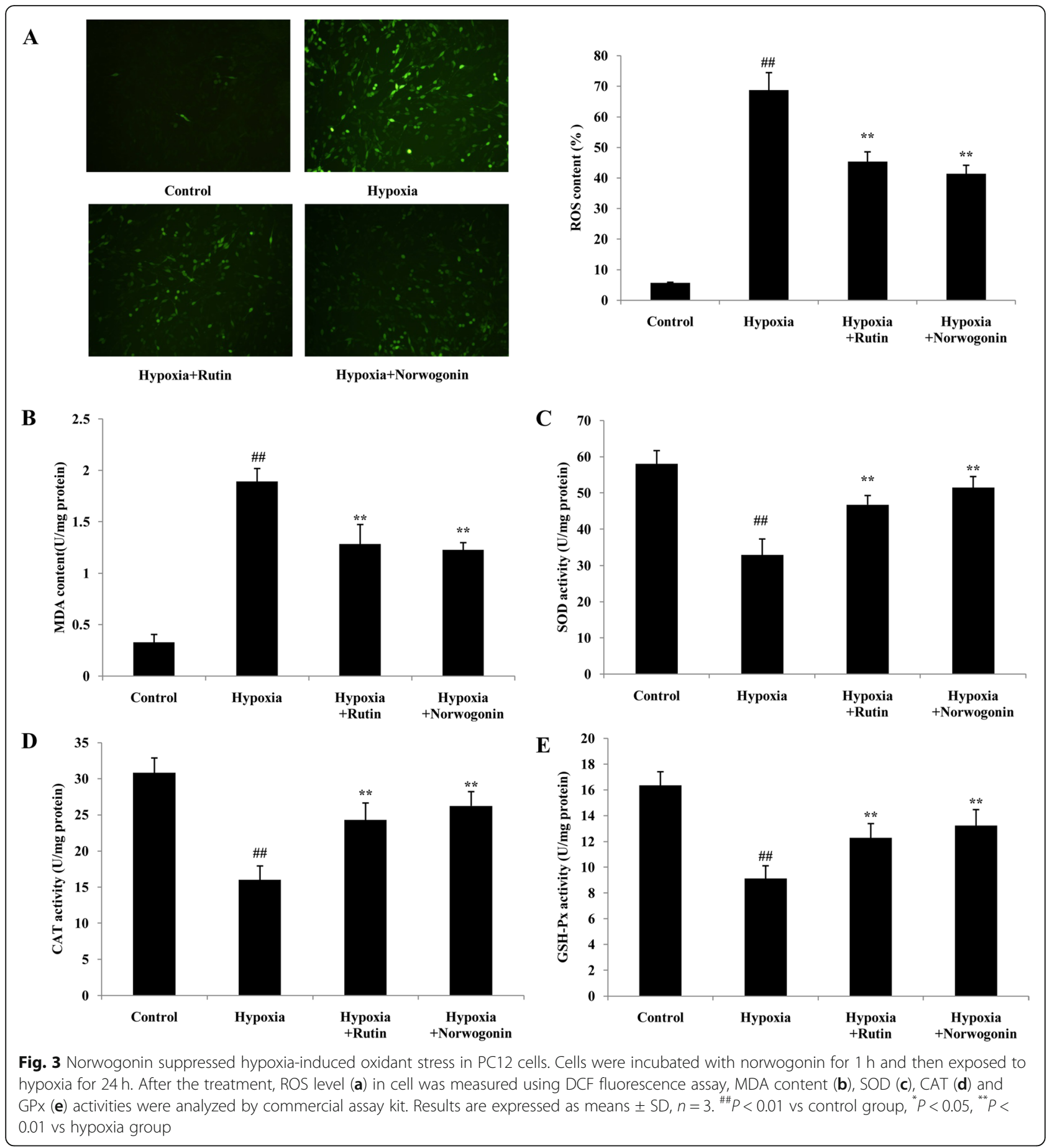

Norwogonin inhibits the increased HIF-1a and VEGF expressions in PC12 cells under hypoxia

As seen in Fig. 4a, the expressions of HIF-1 $\alpha$ and VEGF mRNA in PC12 cells were increased significantly following hypoxia exposure. These changes were inhibited by norwogonin or rutin pretreatment. Similarly, compared to the control group, the expressions of HIF- $1 \alpha$ and VEGF protein were significantly increased in hypoxia group. However, pretreatment of norwogonin or rutin significantly downregulated the protein expression levels of HIF- $1 \alpha$ and VEGF (Fig. 4b-d).

Norwogonin inbibits hypoxia-induced apoptosis in PC12 cells

The effects of norwogonin on hypoxia-induced apoptosis were performed by FCM. As seen in Fig. 5a, compared 


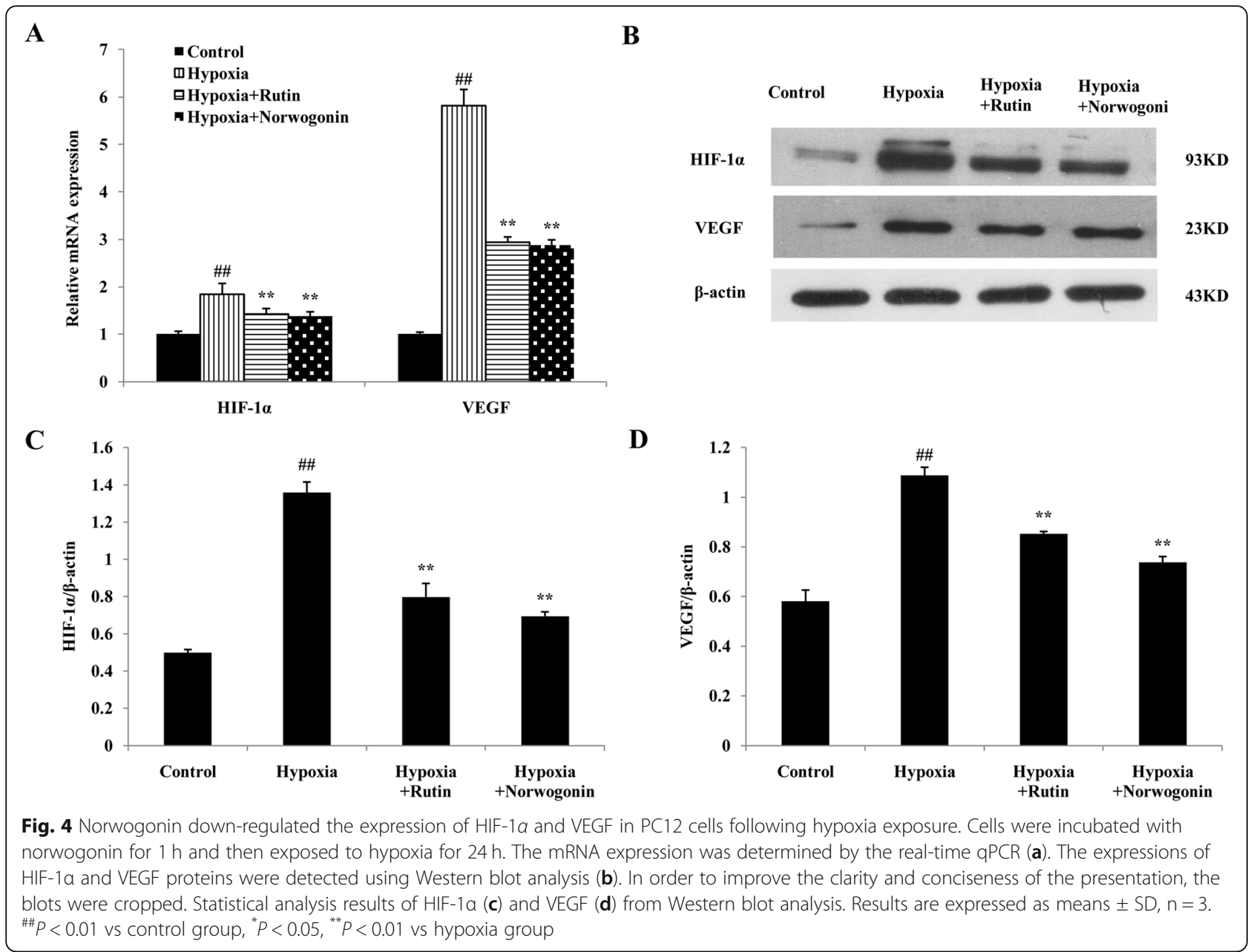

to the normal group, the apoptosis rate of PC12 cells was significantly increased after hypoxia exposure for 24 h. However, norwogonin and rutin significantly inhibited hypoxia-induced apoptosis with the evidence by decreased apoptosis rate of PC12 cells in norwogonin and rutin groups compared with hypoxia group.

To further confirm the anti-apoptotic effect and mechanisms of norwogonin against hypoxia-induced injury, the expressions of apoptosis-related genes and proteins, such as Bcl-2, Bax, cytochrome c and caspase-3, were detected using RT-PCR and western blot analysis. As shown in Fig. 5b, compared with control group, hypoxia exposure significantly increased the level of Bax mRNA and the ratio of $\mathrm{Bax} / \mathrm{Bcl}-2$, and significantly decreased the level of Bcl-2 mRNA in PC12 cells. In contrast, pretreatment with norwogonin or rutin could reverse these effects. Additionally, hypoxia exposure greatly increased the level of cytochrome c mRNA, which was related to mitochondrial dysfunction, while norwogonin and rutin abolished the increased expression level of cytochrome c mRNA induced by hypoxia. Furthermore, hypoxia exposure up-regulated the level of caspase- 3 mRNA in
PC12 cells, which was also blocked by norwogonin or rutin pretreatment. Consistently, changes of $\mathrm{Bcl}-2$, Bax, cytochrome $\mathrm{c}$ and caspase-3 protein expression levels were similar to the trend of mRNA changes (Fig. 6 and Fig. 7).

\section{Discussion}

Recently, much attention has been paid on looking for novel neuroprotective agents with excellent activity and low adverse effects from naturally occurring products [34]. Flavones are one of the largest and widely natural products distributed in plant kingdom [35] and have been extensively used in the pharmaceutical, chemical and nutraceutical industry. It is well known that the free radical scavenging activity of flavones contribute mainly to the presence of hydroxyl groups [36]. Norwogonin owns three phenolic hydroxyl groups (two of them are consecutive hydrogen group) in structure and may have excellent antioxidant activity. Previous study found that norwogonin had weak effect on inhibiting lipopolysaccharide (LPS)- or lipoteichoic acid (LTA) -induced nitric oxide synthase (iNOS) protein expression and nitric 


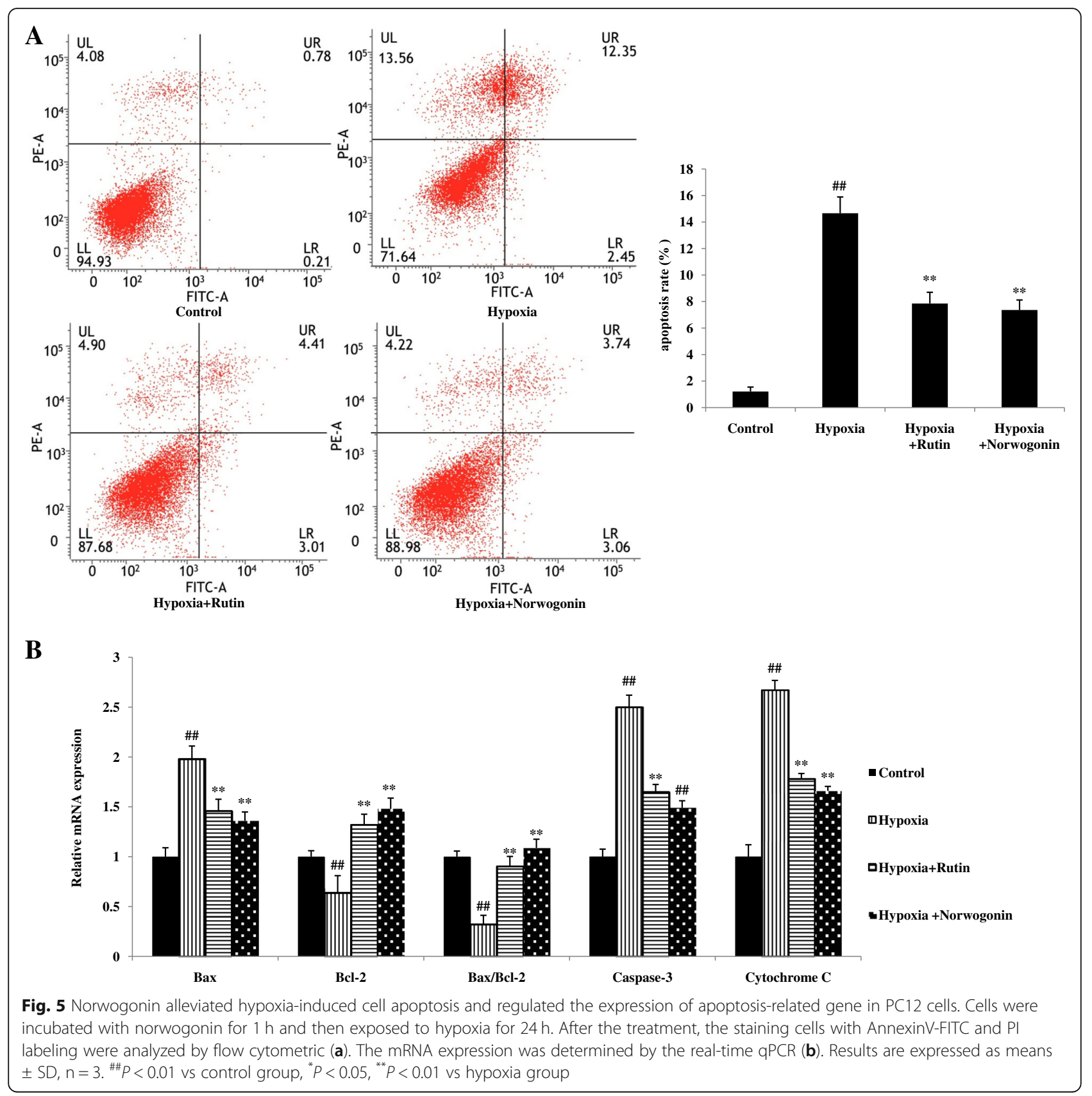

oxide (NO) production [37], but it exhibited better antioxidative activity than acacetin and icariin in protecting human erythrocytes against free-radical-induced haemolysis [25]. Our recent study also demonstrated that norwogonin displayed excellent scavenging activity on $2,2^{\prime}$ diphenyl-2-picrylhydrazyl (DPPH), $\mathrm{O}_{2}{ }^{-}$and $\mathrm{NO}$ in vitro [38]. But the protective effect of norwogonin on hypoxia-induced neurotoxicity remains unclear. PC12 cells, a rat pheochromocytoma cell line, have been extensively considered as a cell line model for screening neuroprotective drugs. In the current study, we used a hypoxia-induced PC12 cells injury model to evaluate the protective effect of norwogonin.

Increasing evidences have indicated that hypoxia exposure results in cytotoxicity in many different cell types, such as hippocampal cells [39] and cardiomyocyte [40]. Hypoxia-induced injury model of PC12 cells has been established in many studies [41, 42]. In line with previous reports, our present result found that the viability of PC12 cells was significantly decreased following hypoxia exposure for $24 \mathrm{~h}$. However, pretreatment with norwogonin prevented the loss of cell viability. In 


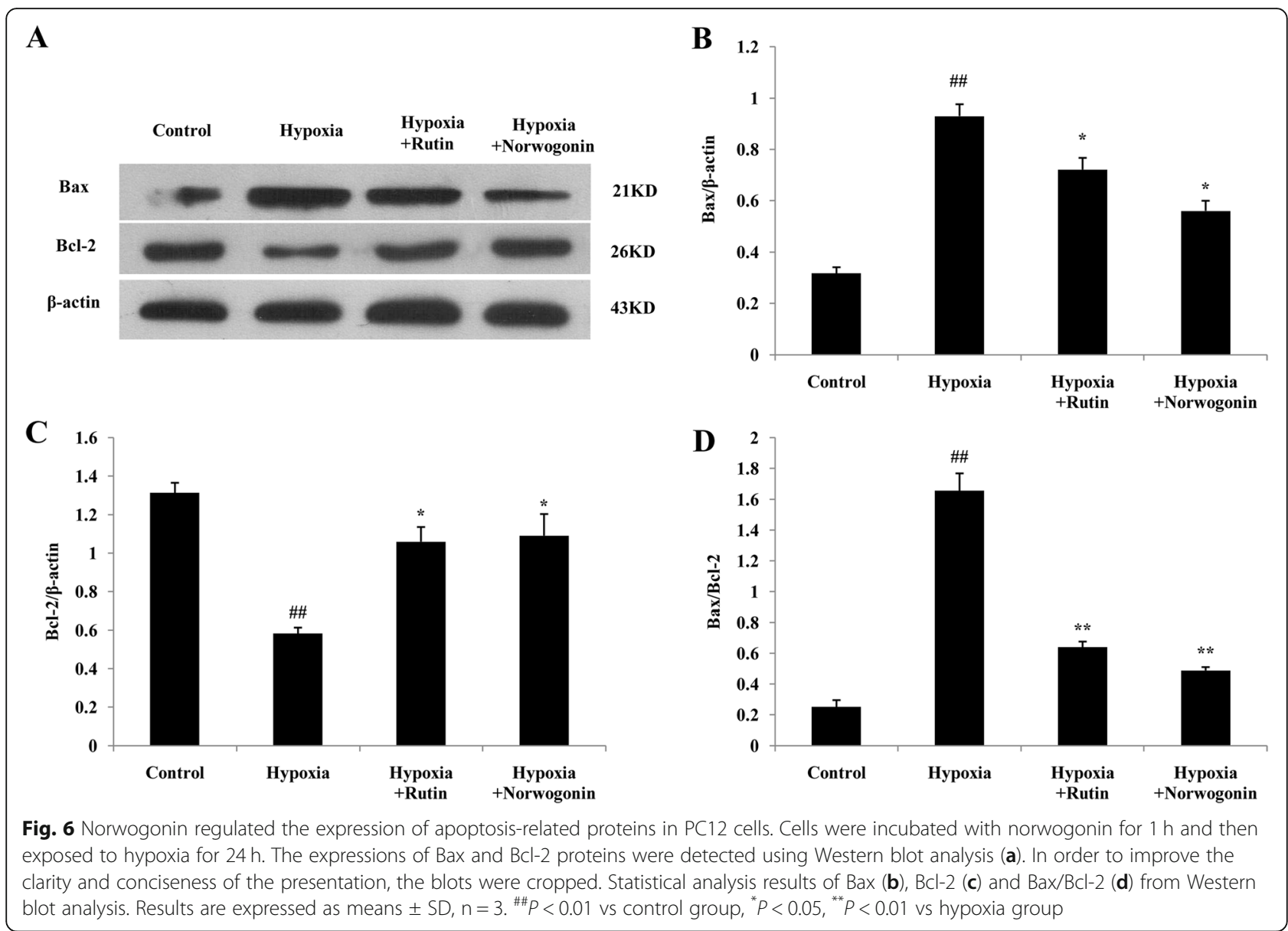

addition, hypoxia exposure caused obvious morphological changes of the cells, while norwogonin reduced these changes and maintained regular shapes of PC12 cells. Furthermore, norwogonin decreased the LDH leakage, suggesting that norwogonin mitigated the cell membrane damage induced by hypoxia.

It has proved that oxidant stress plays a vital role in hypoxia-induced injury. In present study, ROS and MDA content and antioxidant enzymes activities were used to assess the protective effects of norwogonin on hypoxia-induced oxidative stress in PC12 cells. ROS, generated via the mitochondrial electron transport chain, involves physiological roles in cellular signaling pathways at low concentrations, while excessive ROS levels are known to be harmful to major biomolecules such as DNA, lipids, and proteins in cells. In addition, ROS can interact with polyunsaturated lipids in cell membrane, forming MDA, which is widely accepted as a marker of lipid peroxidation. Normally, endogenous antioxidant enzyme, including SOD, CAT and GPx, can effectively remove ROS. However, during hypoxic exposure, excessive ROS directly damage antioxidant enzymes and reduce their activities, resulting in further aggravating oxidative stress in cell [43]. In line with findings from previous reports, our present study also found that hypoxia exposure caused oxidative stress in PC12 cells as evidenced by enhancing the ROS and MDA level, and by decreasing SOD, CAT and GPx activities. Norwogonin pretreatment significantly inhibited intracellular ROS production, decreased MDA levels, and restored the antioxidant enzymes activity, suggesting that norwogonin could ameliorate oxidative stress induced by hypoxia, which was partly due to its up-regulation of antioxidant enzymes.

HIF- $1 \alpha$ is one of the essential transcription factors responding to hypoxia in cell [44]. It is well known that HIF- $1 \alpha$ will be stabilized and increased the expression in hypoxia condition. Some studies have demonstrated that overexpression of HIF- $1 \alpha$ is protective against hypoxic induced injuries $[45,46]$. While other studies indicate that upregulation of HIF- $1 \alpha$ is also considered as a sign of tissue hypoxia [47]. Abundant evidence has corroborated that ROS produced in the mitochondria are responsible for stabilizing HIF- $1 \alpha$ during hypoxia [48]. Therefore, easing the formation ROS, either genetically or pharmacologically, cause downregulation of HIF- $\alpha$ in hypoxia. As expected, our present results showed that hypoxia upregulated the expression of HIF- $1 \alpha$ and 


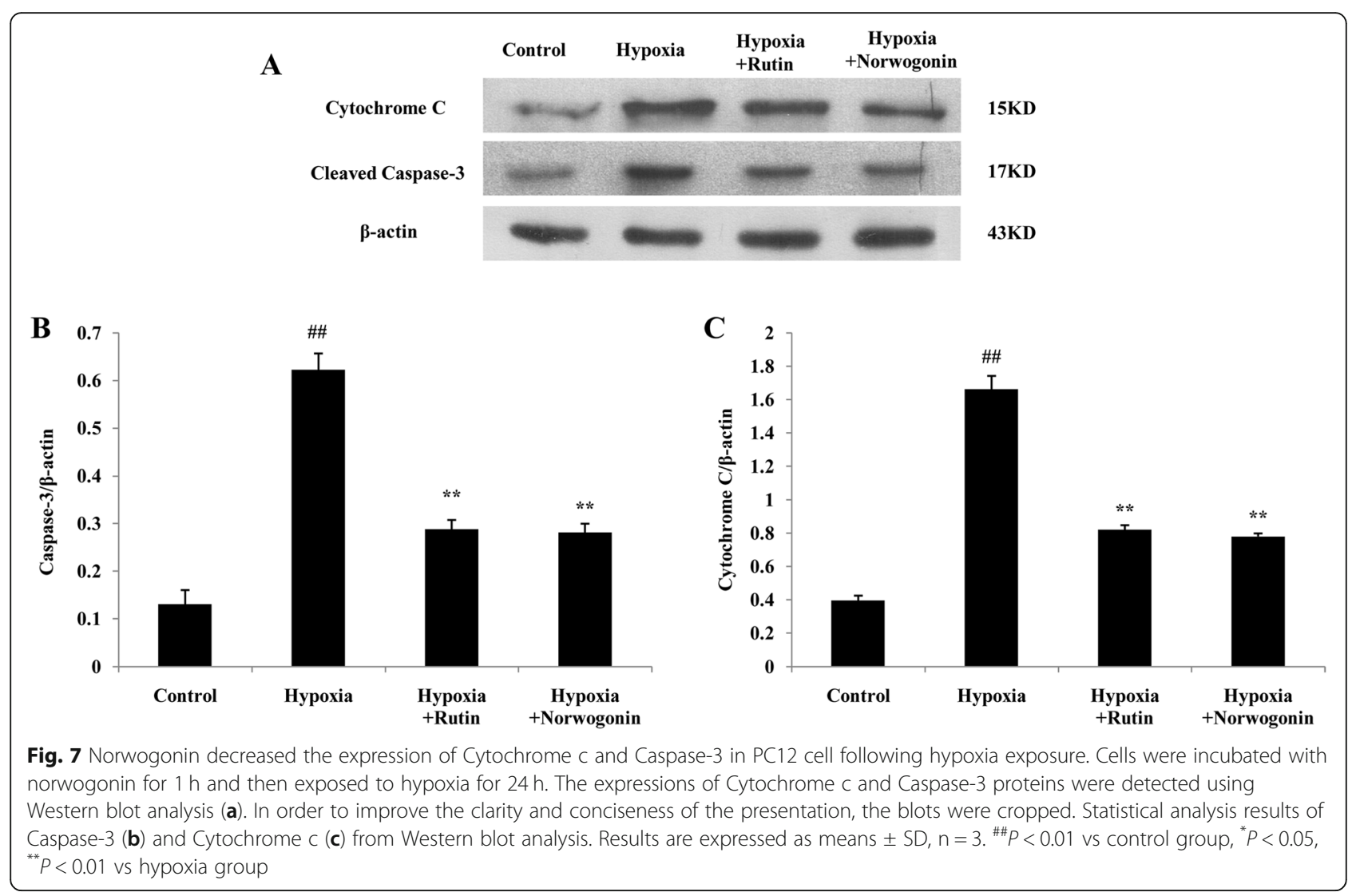

VEGF, which was a downstream target gene of HIF-1. However, pretreatment with norwogonin could reverse these changes by scavenging ROS.

It is well known that apoptosis is closely related to hypoxia-induced damage [49]. Consistent with previous reports, the present study also found that hypoxia exposure for $24 \mathrm{~h}$ significantly induced $\mathrm{PC} 12$ cells apoptosis. Correspondingly, pretreatment with norwogonin reduced cell apoptosis induced by hypoxia. However, our results were inconsistent with another findings that norwogonin effectively induced apoptosis in human leukemia HL-60 cells [26] and in triplenegative breast cancer (TNBC) cells [27]. These contradictory results may be due to the different cell lines and concentration of norwogonin used in the experiments.

Many studies have indicated that hypoxia can induce cell apoptotic via increasing the generation of ROS [50], elevating the expression of HIF1- $\alpha$ [51, 52], activating mitochondrial pathway $[53,54]$, and so on. To further determine whether norwogonin demoted apoptosis via mitochondrial pathway in PC12 cell exposure to hypoxia, the relative levels of apoptosis-related genes and proteins were determined. The bcl-2 family proteins, such as the pro-apoptotic protein Bax and anti-apoptosis protein $\mathrm{Bcl}-2$, play a vital role in the mitochondria-dependent apoptotic pathway [55]. Increasing
$\mathrm{Bcl}-2 / \mathrm{Bax}$ ratio leads the release of cytochrome $\mathrm{c}$, which further promotes the activation of caspase- 3 and leads to apoptotic cell death [56]. Our data revealed that hypoxia exposure for $24 \mathrm{~h}$ activated the mitochondrial apoptosis pathway by upregulating Bax, cytochrome c and cleaved caspase-3 expression and downregulating $\mathrm{Bcl}-2$ expression. However, norwogonin treatment remarkably increased $\mathrm{Bcl}-2$ level and decreased the Bax level in PC12 cells exposed to hypoxia. Furthermore, the increased expressions of cytochrome $\mathrm{c}$ and cleaved caspase- 3 were also reversed by norwogonin. These results suggested that norwogonin could protect $\mathrm{PC} 12$ cells from hypoxia-induced injury via mitochondrial-dependent apoptosis pathway.

\section{Conclusion}

In conclusion, our results firstly suggested that norwogonin exhibited excellent protective effects on hypoxia-induced oxidative stress and apoptosis in PC12 cells by scavenging ROS, maintaining the activity of antioxidant enzymes and inhibiting mitochondrial apoptosis pathway.

\section{Supplementary Information}

The online version contains supplementary material available at https://doi. org/10.1186/s12906-020-03189-8.

\section{Additional file 1.}




\section{Abbreviations}

ROS: Reactive oxygen species; LDH: Lactate dehydrogenase; MDA: Malondialdehyde; SOD: Superoxide dismutase; CAT: Catalase; GPx: Glutathione peroxidase; HIF-1a: Hypoxia inducible factor-1a; VEGF: Vascular endothelial growth factor; $\mathrm{BCl}-2$ : B cell lymphoma-2; Bax: $\mathrm{BCl}-2$ associated X protein; Akt: Protein kinase B; AMPK: AMP-activated protein kinase; DMSO: Dimethyl sulfoxide; DMEM: Dulbecco's modified Eagle's medium; FBS: Fetal bovine serum; MTT: (3-(4,5-dimethylthiazol-2-yl)-2,5diphenyltetrazolium bromide) tetrazolium; HE: Hematoxylin-Eosin; DCFHDA: 2',7'-dichlorodihydrofluorescein diacetate; BCA: Bicinchoninic acid; RIPA: Radioimmunoprecipitationassay; PVDF: Polyvinylidene fluoride; GAPD H: Glyceraldehyde-3-phosphate dehydrogenase; ECL: Enhanced chemiluminescence; ANOVA: Analysis of variance; DPPH: 2,2'-diphenyl-2picrylhydrazyl; BNIP3: BCl-2 interacting protein 3; LPS: Ipopolysaccharide; LTA: Lipoteichoic acid; NO: Nitric oxide; iNOS: Nitric oxide synthase; TNBC: triple-negative breast cancer.

\section{Acknowledgements}

No application.

\section{Authors' contributions}

$L, Z J$ and HM designed the research; RG, LH, JZ, AZ and JS conducted experiments; LJ, RG, DW and JZ analyzed data and interpreted results of experiments; LJ and RG drafted manuscript; ZJ and HM edited and revised manuscript. All authors revised the final manuscript and all authors read and approved the final manuscript.

\section{Funding}

This study was supported by the National Natural Science Foundation of China (Grant numbers 81872796, 81202458, 81571847), China Postdoctoral Science Foundation (Grant number 2015ZXKF09), Natural Science Foundation of Gansu Province (Grant numbers 18JR3RA408, 1308RJYA061, 145RJZA089) and The Logistics Research Program of PLA (Grant number CWH17J010, CLB18J028). The funding body allowed to the design of the study and collection, analysis, and interpretation of data and in writing the manuscript.

\section{Availability of data and materials}

The datasets used and/or analyzed during the current study available from the corresponding author on reasonable request.

\section{Ethics approval and consent to participate}

No application.

\section{Consent for publication}

No application.

\section{Competing interests}

The authors declare that they have no conflicts of interest.

Received: 4 August 2020 Accepted: 14 December 2020

Published online: 07 January 2021

\section{References}

1. West JB. High-altitude medicine. Am J Respir Crit Care Med. 2012;186(12): 1229-37.

2. Ferdinand $P$, Roffe $C$. Hypoxia after stroke: a review of experimental and clinical evidence. Exp Transl Stroke Med. 2016;8(1):9.

3. Garbarino VR, Orr ME, Rodriguez KA, Buffenstein R. Mechanisms of oxidative stress resistance in the brain: lessons learned from hypoxia tolerant extremophilic vertebrates. Arch Biochem Biophys. 2015;576:8-16.

4. Zaghloul N, Patel H, Codipilly C, Marambaud P, Dewey S, Frattini S, et al. Overexpression of extracellular superoxide dismutase protects against brain injury induced by chronic hypoxia. PLoS One. 2014;9(9):e108168.

5. Zhu M, Xu M, Zhang K, Li J, Ma H, Xia G, et al. Effect of acute exposure to hypobaric hypoxia on learning and memory in adult Sprague-Dawley rats. Behav Brain Res. 2019:367:82-90.

6. Wang X, Hou Y, Li Q, Li X, Wang W, Ai X, et al. Rhodiola crenulata attenuates apoptosis and mitochondrial energy metabolism disorder in rats with hypobaric hypoxia-induced brain injury by regulating the HIF-1a/
microRNA 210/ISCU1/2(COX10) signaling pathway. J Ethnopharmacol. 2019; 241:111801.

7. Wang X, Li J, Wu D, Bu X, Qiao Y. Hypoxia promotes apoptosis of neuronal cells through hypoxia-inducible factor-1alpha-microRNA-204-B-cell lymphoma-2 pathway. Exp Biol Med (Maywood). 2016;241(2):177-83.

8. Lakshmi Sundaram R, Vasanthi HR. Dalspinin isolated from Spermacoce hispida (Linn.) protects H9c2 cardiomyocytes from hypoxic injury by modulating oxidative stress and apoptosis. J Ethnopharmacol. 2019;241: 111962.

9. Blomgren $\mathrm{K}$, Hagberg $\mathrm{H}$. Free radicals, mitochondria, and hypoxia-ischemia in the developing brain. Free Radic Biol Med. 2006;40(3):388-97.

10. Rao VK, Carlson EA, Yan SS. Mitochondrial permeability transition pore is a potential drug target for neurodegeneration. Biochim Biophys Acta. 2014; 1842(8):1267-72.

11. Akao M, O'Rourke B, Teshima Y, Seharaseyon J, Marban E. Mechanistically distinct steps in the mitochondrial death pathway triggered by oxidative stress in cardiac myocytes. Circ Res. 2003:92(2):186-94.

12. Elmore S. Apoptosis: a review of programmed cell death. Toxicol Pathol 2007:35(4):495-516.

13. Guaiquil VH, Golde DW, Beckles DL, Mascareno EJ, Siddiqui MA. Vitamin C inhibits hypoxia-induced damage and apoptotic signaling pathways in cardiomyocytes and ischemic hearts. Free Radic Biol Med. 2004;37(9):1419-29.

14. Fan $P C, M a H P$, Jing $L L$, Li L, Jia ZP. The antioxidative effect of a novel free radical scavenger 4'-hydroxyl-2-substituted phenylnitronyl nitroxide in acute high-altitude hypoxia mice. Biol Pharm Bull. 2013;36(6):917-24.

15. Catarino MD, Alves-Silva JM, Pereira OR, Cardoso SM. Antioxidant capacities of flavones and benefits in oxidative-stress related diseases. Curr Top Med Chem. 2015;15(2):105-19.

16. Nakayama M, Aihara M, Chen YN, Araie M, Tomita-Yokotani K, Iwashina T. Neuroprotective effects of flavonoids on hypoxia-, glutamate-, and oxidative stress-induced retinal ganglion cell death. Mol Vis. 2011;17:1784-93.

17. Sundaram RL, Sali VK, Vasanthi HR. Protective effect of rutin isolated from Spermococe hispida against cobalt chloride-induced hypoxic injury in H9c2 cells by inhibiting oxidative stress and inducing apoptosis. Phytomedicine. 2018:51:196-204.

18. Liu F, Zhang H, Li Y, Lu X. Nobiletin suppresses oxidative stress and apoptosis in $\mathrm{H} 9 \mathrm{c} 2$ cardiomyocytes following hypoxia/reoxygenation injury. Eur J Pharmacol. 2019:854:48-53.

19. Wu WY, Li YD, Cui YK, Wu C, Hong YX, Li G, et al. The natural flavone Acacetin confers Cardiomyocyte protection against hypoxia/Reoxygenation injury via AMPK-mediated activation of Nrf2 signaling pathway. Front Pharmacol. 2018:9:497.

20. Popova TP, Litvinenko VI, Kovalev IP. Flavones of the roots of Scutellaria baicalensis. Chem Nat Compd. 1973:9(6):699.

21. Liu G, Rajesh N, Wang X, Zhang M, Wu Q, Li S, et al. Identification of flavonoids in the stems and leaves of Scutellaria baicalensis Georgi. J Chromatogr B. 2011;879(13):1023-8.

22. Sordon S, Madej A, Poplonski J, Bartmanska A, Tronina T, Brzezowska E, et al. Regioselective ortho-Hydroxylations of flavonoids by yeast. J Agric Food Chem. 2016;64(27):5525-30.

23. Yuan $\mathrm{H}$, Ye J, Chen H, Zhao Z, Luo X, Zhang W, et al. Facile synthesis of norwogonin, isoscutellarein, and herbacetin. Tetrahedron Lett. 2016;57(30): 3389-91.

24. Jing LL, Fan XF, Jia ZP, Fan PC, Ma HP. Convergent synthesis of moslosooflavone, isowogonin and norwogonin from chrysin. Nat Prod Commun. 2015;10(3):387-8.

25. Liu ZQ, Luo XY, Sun YX, Wu W, Liu CM, Liu ZQ, et al. The antioxidative effect of icariin in human erythrocytes against free-radical-induced haemolysis. J Pharm Pharmacol. 2004;56(12):1557-62

26. Chow JM, Huang GC, Shen SC, Wu CY, Lin CW, Chen YC. Differential apoptotic effect of wogonin and nor-wogonin via stimulation of ROS production in human leukemia cells. J Cell Biochem. 2008;103(5):1394-404.

27. Abd El-Hafeez AA, Khalifa HO, Mahdy EAM, Sharma V, Hosoi T, Ghosh P, et al. Anticancer effect of nor-wogonin (5, 7, 8-trihydroxyflavone) on human triple-negative breast cancer cells via downregulation of TAK1, NF-kappaB, and STAT3. Pharmacol Rep. 2019;71(2):289-98.

28. Choi HJ, Song HH, Lee JS, Ko HJ, Song JH. Inhibitory effects of Norwogonin, Oroxylin a, and Mosloflavone on Enterovirus 71. Biomol Ther (Seoul). 2016; 24(5):552-8

29. Miyasaki Y, Rabenstein JD, Rhea J, Crouch ML, Mocek UM, Kittell PE, et al. Isolation and characterization of antimicrobial compounds in plant extracts 
against multidrug-resistant Acinetobacter baumannii. PLoS One. 2013;8(4): e61594.

30. Hodnick WF, Duval DL, Pardini RS. Inhibition of mitochondrial respiration and cyanide-stimulated generation of reactive oxygen species by selected flavonoids. Biochem Pharmacol. 1994;47(3):573-80.

31. Luo H, Sun W, Shao J, Ma H, Jia Z, Jing L. Protective effect of nitronyl nitroxide against hypoxia-induced damage in PC12 cells. Biochem Cell Biol. 2020;98(3):345-53.

32. Fischer AH, Jacobson KA, Rose J, Zeller R. Hematoxylin and eosin staining of tissue and cell sections. CSH Protoc. 2008;3(5):pdb.prot4986.

33. Eruslanov E, Kusmartsev S. Identification of ROS using oxidized DCFDA and flow-cytometry. Methods Mol Biol. 2010;594:57-72.

34. Sowndhararajan K, Deepa P, Kim M, Park SJ, Kim S. Baicalein as a potent neuroprotective agent: a review. Biomed Pharmacother. 2017;95:1021-32.

35. Nijveldt RJ, van Nood E, van Hoorn DE, Boelens PG, van Norren K, van Leeuwen PA. Flavonoids: a review of probable mechanisms of action and potential applications. Am J Clin Nutr. 2001;74(4):418-25.

36. Rice-Evans CA, Miller NJ, Paganga G. Structure-antioxidant activity relationships of flavonoids and phenolic acids. Free Radic Biol Med. 1996; 20(7):933-56.

37. Huang GC, Chow JM, Shen SC, Yang LY, Lin CW, Chen YC. Wogonin but not nor-wogonin inhibits lipopolysaccharide and lipoteichoic acid-induced iNOS gene expression and NO production in macrophages. Int Immunopharmacol. 2007;7(8):1054-63.

38. Zhang Q, Shao J, Zhao T, He L, Ma H, Jing L. The role of C-8 OH on the antioxidant activity of Norwogonin and Isowogonin. Nat Prod Commun. 2020;15(5):1-7.

39. Rzemieniec J, Litwa E, Wnuk A, Lason W, Golas A, Krzeptowski W, et al. Neuroprotective action of raloxifene against hypoxia-induced damage in mouse hippocampal cells depends on ERalpha but not ERbeta or GPR30 signalling. J Steroid Biochem Mol Biol. 2015;146:26-37.

40. Shi YN, Zhang XQ, Hu ZY, Zhang CJ, Liao DF, Huang HL, et al. Genistein protects H9c2 Cardiomyocytes against chemical hypoxia-induced injury via inhibition of apoptosis. Pharmacology. 2019;103(5-6):282-90.

41. Jing L, Ma H, Fan P, Gao R, Jia Z. Antioxidant potential, total phenolic and total flavonoid contents of Rhododendron anthopogonoides and its protective effect on hypoxia-induced injury in PC12 cells. BMC Complement Altern Med. 2015;15:287.

42. Zhou B, Liu HY, Zhu BL. Protective role of SOCS3 modified bone marrow Mesenchymal stem cells in hypoxia-induced injury of PC12 cells. J Mol Neurosci. 2019;67(3):400-10.

43. Zhang BZ, Guo XT, Chen JW, Zhao Y, Cong X, Jiang ZL, et al. Saikosaponin$D$ attenuates heat stress-induced oxidative damage in LLC-PK1 cells by increasing the expression of anti-oxidant enzymes and HSP72. Am J Chin Med. 2014;42(5):1261-77.

44. Choudhry H, Harris AL. Advances in hypoxia-inducible factor biology. Cell Metab. 2018;27(2):281-98.

45. Yu H, Chen B, Ren Q. Baicalin relieves hypoxia-aroused H9c2 cell apoptosis by activating Nrf2/HO-1-mediated HIF1a/BNIP3 pathway. Artif Cells Nanomed Biotechnol. 2019;47(1):3657-63.

46. Wang K, Lei J, Zou J, Xiao H, Chen A, Liu X, et al. Mipu1, a novel direct target gene, is involved in hypoxia inducible factor 1-mediated cytoprotection. PLoS One. 2013;8(12):e82827.

47. Covenas R, Gonzalez-Fuentes J, Rivas-Infante E, Lagartos-Donate MJ, Cebada-Sanchez S, Arroyo-Jimenez MM, et al. Developmental study of the distribution of hypoxia-induced factor-1 alpha and microtubule-associated protein 2 in children's brainstem: comparison between controls and cases with signs of perinatal hypoxia. Neuroscience. 2014;271:77-98.

48. Movafagh S, Crook S, Vo K. Regulation of hypoxia-inducible factor-1a by reactive oxygen species: new developments in an old debate. J Cell Biochem. 2015;116(5):696-703.

49. Lenihan $C R$, Taylor $C T$. The impact of hypoxia on cell death pathways. Biochem Soc Trans. 2013;41(2):657-63.

50. Redza-Dutordoir M, Averill-Bates DA. Activation of apoptosis signalling pathways by reactive oxygen species. Biochim Biophys Acta. 2016;1863(12): 2977-92.

51. Sendoel A, Hengartner MO. Apoptotic cell death under hypoxia. Physiology (Bethesda). 2014;29(3):168-76

52. Zhao X, Ma C, Li R, Xue J, Liu L, Liu P. Hypoxia induces apoptosis through HIF-1a signaling pathway in human Uterosacral ligaments of pelvic organ prolapse. Biomed Res Int. 2017;2017:8316094.
53. Tanaka T, Miyata T, Inagi R, Kurokawa K, Adler S, Fujita T, et al. Hypoxiainduced apoptosis in cultured glomerular endothelial cells: involvement of mitochondrial pathways. Kidney Int. 2003;64(6):2020-32.

54. Yin J, Ni B, Liao WG, Gao YQ. Hypoxia-induced apoptosis of mouse spermatocytes is mediated by HIF-1a through a death receptor pathway and a mitochondrial pathway. J Cell Physiol. 2018;233(2):1146-55.

55. Youle RJ, Strasser A. The BCL-2 protein family: opposing activities that mediate cell death. Nat Rev Mol Cell Biol. 2008;9(1):47-59.

56. Bras M, Queenan B, Susin SA. Programmed cell death via mitochondria: different modes of dying. Biochemistry (Mosc). 2005;70(2):231-9.

\section{Publisher's Note}

Springer Nature remains neutral with regard to jurisdictional claims in published maps and institutional affiliations.

\section{Ready to submit your research? Choose BMC and benefit from:}

- fast, convenient online submission

- thorough peer review by experienced researchers in your field

- rapid publication on acceptance

- support for research data, including large and complex data types

- gold Open Access which fosters wider collaboration and increased citations

- maximum visibility for your research: over $100 \mathrm{M}$ website views per year

At BMC, research is always in progress.

Learn more biomedcentral.com/submissions 